\title{
The Role of Ponds in Pesticide Dissipation at the Agricultural Catchment Scale: A Critical Review
}

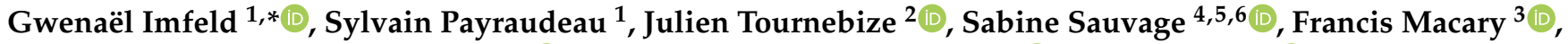

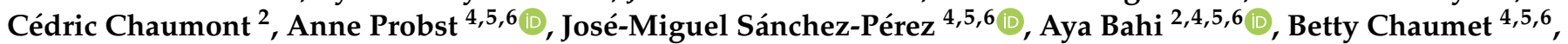 \\ Tetyana Gilevska ${ }^{1}$, Hugues Alexandre ${ }^{4,5,6}$ and Jean-Luc Probst ${ }^{4,5,6}$ (i)
}

1 Institut Terre et Environnement de Strasbourg (ITES), University of Strasbourg/EOST/ENGEES, CNRS UMR 7063, 5 rue Descartes, F-67084 Strasbourg, France; sylvain.payraudeau@engees.unistra.fr (S.P.); gilevska@unistra.fr (T.G.)

2 HYCAR-Artemhys, INRAE, University of Paris-Saclay, CS 10030, F-92761 Antony, France; julien.tournebize@inrae.fr (J.T.); cedric.chaumont@irstea.fr (C.C.); aya.bahi@inrae.fr (A.B.)

3 ETBX, INRAE, F-33612 Cestas-Gazinet, France; francis.macary@irstea.fr

4 Laboratoire Ecologie Fonctionnelle et Environnement, University of Toulouse, CNRS, UPS, Toulouse INP, Campus ENSAT, Avenue de l'Agrobiopole, Castanet Tolosan, F-31326 Toulouse, France; sabine.sauvage@univ-tlse3.fr (S.S.); anne.probst@ensat.fr (A.P.); jose-miguel.sanchez-perez@univ-tlse3.fr (J.-M.S.-P.); betty.chaumet@toulouse-inp.fr (B.C.); hugues.alexandre@univ-tlse3.fr (H.A.); jean-luc.probst@ensat.fr (J.-L.P.)

5 LTSER Zone Atelier Pyrénées-Garonne, University of Toulouse, CNRS, Castanet Tolosan, F-31320 Toulouse, France

6 LTER Auradé Experimental Catchment, IR OZCAR, University of Toulouse, CNRS, Castanet Tolosan, F-31320 Toulouse, France

check for updates

Citation: Imfeld, G.; Payraudeau, S.; Tournebize, J.; Sauvage, S.; Macary, F.; Chaumont, C.; Probst, A.;

Sánchez-Pérez, J.-M.; Bahi, A.;

Chaumet, B.; et al. The Role of Ponds in Pesticide Dissipation at the Agricultural Catchment Scale: A Critical Review. Water 2021, 13, 1202. https://doi.org/10.3390/w13091202

Academic Editor: Richard Cooper

Received: 16 February 2021

Accepted: 23 April 2021

Published: 26 April 2021

Publisher's Note: MDPI stays neutral with regard to jurisdictional claims in published maps and institutional affiliations.

Copyright: (c) 2021 by the authors. Licensee MDPI, Basel, Switzerland. This article is an open access article distributed under the terms and conditions of the Creative Commons Attribution (CC BY) license (https:/ / creativecommons.org/licenses/by/ $4.0 /)$.
* Correspondence: imfeld@unistra.fr; Tel.: +333-6885-0474

\begin{abstract}
Ponds in agricultural areas are ubiquitous water retention systems acting as reactive biogeochemical hotspots controlling pesticide dissipation and transfer at the catchment scale. Several issues need to be addressed in order to understand, follow-up and predict the role of ponds in limiting pesticide transfer at the catchment scale. In this review, we present a critical overview of functional processes underpinning pesticide dissipation in ponds. We highlight the need to distinguish degradative and non-degradative processes and to understand the role of the sedimentwater interface in pesticide dissipation. Yet it is not well-established how pesticide dissipation in ponds governs the pesticide transfer at the catchment scale under varying hydro-climatic conditions and agricultural operation practices. To illustrate the multi-scale and dynamic aspects of this issue, we sketch a modelling framework integrating the role of ponds at the catchment scale. Such an integrated framework can improve the spatial prediction of pesticide transfer and risk assessment across the catchment-ponds-river continuum to facilitate management rules and operations.
\end{abstract}

Keywords: pesticide transport; pesticide transformation and dissipation; ponds; biogeochemical processes; agricultural catchment; agro-ecological modelling

\section{Introduction}

The use of pesticides in agriculture contributes to non-point source pollution of continental water, threatening drinking water resources and aquatic ecosystems. Europe is a major pesticide consumer worldwide, with France, Germany and Spain being the biggest users in the European Union [1]. New pesticide commercial formulations appear each year due to modern industry and substitutions following regulations. Despite the recently implemented directives [2], the recurrent detection and persistence of pesticides and their transformation products in surface aquatic ecosystems and groundwater emphasizes the difficulties of using regulations to protect the environment [3]. Transformation products are often unknown and may be more toxic and/or persistent than their parent pesticides. At the agricultural catchment scale, intense and long runoff events following pesticide application 
mainly drive the transfer of pesticides and their transformation products towards surface waters [4-6]. As a result, pesticide concentrations exceeding drinking water standards are observed in more than $90 \%$ of surface waters in France. This leads to restricted use of some pesticides to protect drinking water supplies and to reach good chemical status of waterbodies [7].

In this context, evaluating and predicting the transfer of pesticides from agricultural lands into surface waters is crucial and requires integrative studies accounting for prevailing zones and periods of pesticide dissipation and storage. Ponds are prevailing zones of pesticide dissipation in agricultural catchments, although they are primarily constructed for water storage and irrigation purposes. Ponds can intercept pesticide runoff and act as buffering areas in the agricultural landscape. Leading studies of the literature have addressed the pesticide transfer at different scales of agricultural basins (e.g., [4,6,8-15]) and emphasize the role of ponds in reducing pesticide transfer. Ponds can thus be considered as an "off-farm" and "off-fields" mitigation strategy to limit at the catchment scale pesticide transfer towards downstream surface waters $[11,13,15,16]$. As defined here, a pond is a small body of still water, generally smaller ( $<2 \mathrm{ha})$ and shallower than a lake, formed naturally or by artificial means [14]. Ponds are temporally or permanently flooded by water and can be colonized by macrophytes. Using this definition, ponds include constructed stormwater ponds and artificial wetlands.

Ponds are dynamic systems where biological, chemical and physical processes interact to dissipate a variety of pollutants in upstream water, including pesticides $[15,17,18]$. Pesticide dissipation in ponds results from both degradative and non-degradative processes determining the amount of a pesticide at a given time, in a given pond compartment. Ponds favor pesticide dissipation processes, including hydrolysis, photolysis, sedimentation, sorption, biodegradation, and plant uptake, by increasing at the catchment scale both the water residence time and the pesticide reaction time $[19,20]$. On the other hand, ponds can act as a secondary source of delayed pollution through the remobilization of previously accumulated dissolved and solid-bound pesticides following a storm event [10], and favor the export of transformation products [21]. Yet the interplay between dissipation processes involved in the storage, transformation and transport of pesticides within ponds is poorly understood.

In addition, only few studies have integrated the role of ponds in agricultural ecosystem management and related pesticide dissipation in ponds to pesticide transfer at the catchment scale. Integrating the role of ponds in agro-hydrological models accounting for the interlocked scales from the headwater catchment to larger river basins remains challenging $[8,12,22-24]$. Whenever existing, the capacity of ponds to dissipate pesticides is generally considered in models without validation steps relying on field measurements. Altogether, this results in large uncertainties concerning the predictions of pesticide transfer, risk assessment and exposure level at the river-basin scale.

\section{Scope of the Review}

In this review, we addressed two issues which need to be solved to integrate the role of ponds in controlling pesticide transfer at the catchment and river-basin scales. The first issue lies in the evaluation of degradative and non-degradative processes contributing to pesticide dissipation in the pond compartments, including the sediment-water interface (SWI). The second issue is the integration of the role of ponds in agricultural catchment to predict pesticide transfer under varying hydro-climatic conditions, land cover and agricultural practices. To explore this second issue, we sketched an integrative modelling framework (Figure 1) currently developed in France within the PESTIPOND project (see Supplementary Materials for detailed information). 

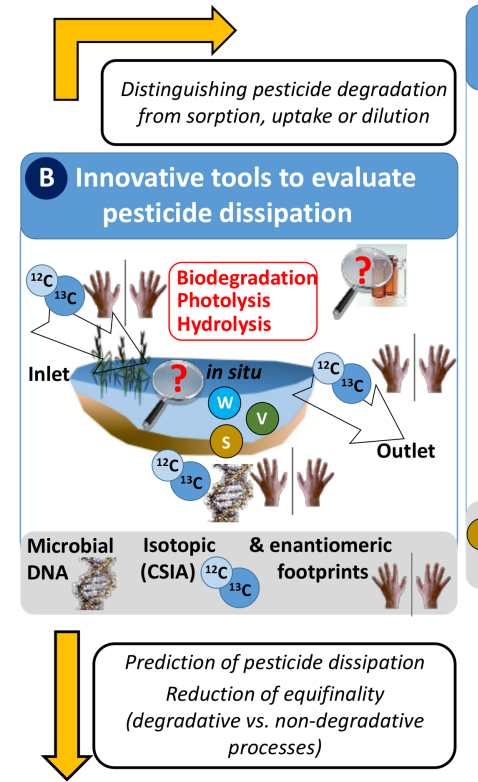

\section{A Fluxes, processes \& compartments} Artificial drainage Transpiration Runoff (DOC, Erosion (TSS, $\mathrm{P}$ )
$\mathrm{POC}$

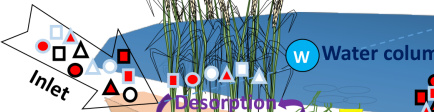
Rhizosphere n sorption 7 , - $010.9 \mathrm{Pl}$

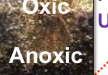

$$
\text { ce }
$$

$$
\text { Groundwater }
$$

(3) $v$ Pond $\Rightarrow$ Pesticide dissipation: $\quad$ Mixture of pesticides In dissolved compartments Water Degradative processes Transformation products or o particulate

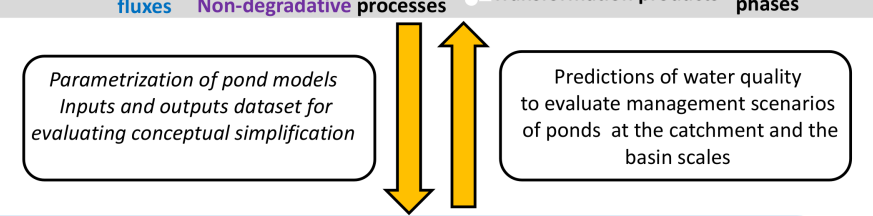

C Proposed modelling framework and associated steps

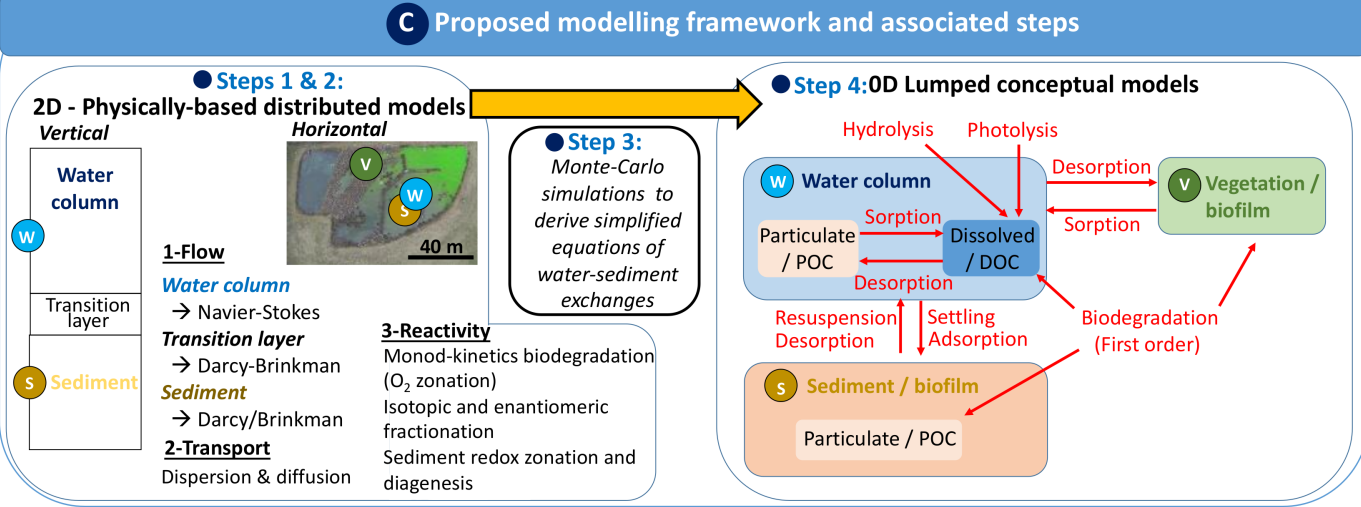

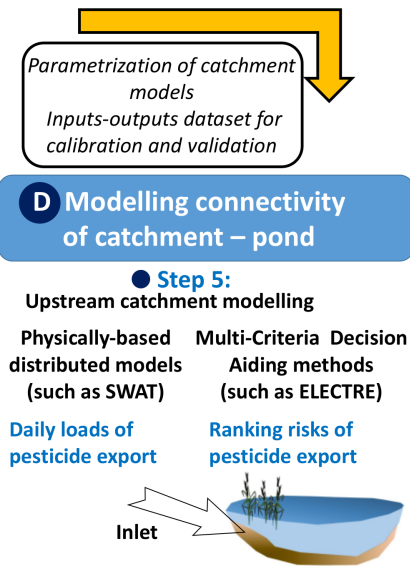

Pond typology \& Connectivity scenarios

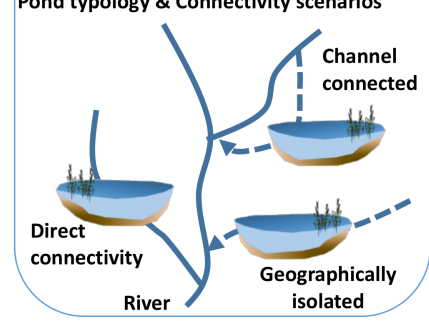

Definition and integration in catchmen of dissipation in ponds (OD modelling for ponds)

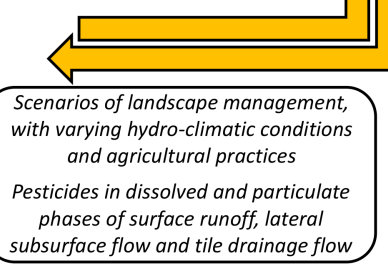

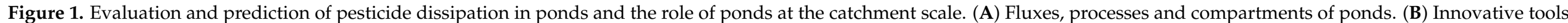

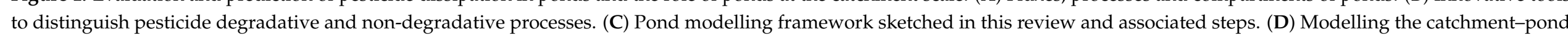

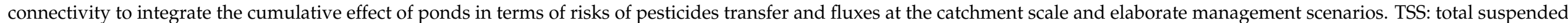
solids; DOC: dissolved organic carbon; N: nitrogen; P: phosphorus; POC: particulate organic carbon. 


\section{Probing Pesticide Dissipation in Ponds: Blindspots and Opportunities}

Available approaches to examine pesticide dissipation in ponds and to establish mass balances allow monitoring and sometime quantifying the capacity of ponds to dissipate dissolved and solid-bound pesticides [25]. Literature surveys highlighted that artificial ponds can reduce pesticide masses by $50 \%$ on average (see $[13,18,26]$ for reviews). Inlet and outlet pesticide loads are typically calculated based on concentrations and water discharges to estimate the dissipation efficiency of ponds (Figure 1A). The overall mass transfer of pesticides in ponds can be estimated accounting for variable inputs and dynamic hydroclimatic conditions $[13,18,26]$. However, the contribution of pesticide dissipation processes to the overall dissipation in relation to temperature, water residence time, hydrological conditions or vegetation dynamics (Figure 1A), remains poorly quantified so far.

In particular, the contribution of degradative and non-degradative processes driving the pesticide dissipation in ponds is generally not addressed (Figure 1A). While pesticide fluxes in ponds could be reduced by $50-80 \%$ when the water retention time increases by one order of magnitude [9], the contribution of individual dissipation processes to the overall dissipation remains elusive. The sediment-water interface (SWI) is a specific hot-spot of dissipation, involving both biological and physico-chemical processes, and conferring upon ponds a substantial dissipation potential [27]. However, little is known about the interplay of hydrological and biogeochemical processes affecting pesticide storage and transformation at the SWI. In addition, microorganisms associated with pesticide biodegradation in ponds and the SWI are often unknown and remain unidentified in situ.

\subsection{Distinguishing Degradative and Non-Degradative Processes Driving Pesticide Dissipation}

Pesticide dissipation within the different ponds compartments involves both nondegradative processes, such as sorption, and degradative processes, including photolysis, hydrolysis and biodegradation (Figure 1A). An evaluation of pesticide degradation is essential to quantify the net mass decrease of parent pesticides but also to infer information on prevailing transformation pathways in relation to the production of potentially toxic and persistent transformation products [3]. Recent advances in stable isotope chemistry [28] and DNA-based biomolecular tools [29], that can be deployed on different time and spatial scales, may help to address these challenges (Figure 1B).

\subsubsection{Evaluating Pesticide Biodegradation in Ponds Using Isotope Analysis}

Beyond the traditional "input-output" mass balance, several studies focused on pesticide dynamics in different compartments and sub-compartments of ponds, including dissolved/suspended phases, top layers of the bottom sediment, macrophyte rhizosphere, roots, stems, leaves [10] and biofilms [30-32]. Most studies on pesticide dynamics in ponds currently rely on conventional approaches, based on concentrations of pesticides and their transformation products. However, these studies generally fail to determine where, when and how pesticide degradation occurs in ponds as a decrease of concentration in water might also refer to dilution or sorption. In addition, further dissipation of transformation products in ponds may severely limit the prediction of transformation pathways even when high-resolution mass spectrometry (HRMS) screening is used [33]. Hence, closing the mass balance of pesticides in complex, dynamic and multi-compartmented ponds is often uncertain and requires novel approaches.

In this context, compound-specific isotope analysis (CSIA) may be useful to identify degradation and transformation pathways of pesticides in ponds (Figure 1B), even if no transformation products are detected [28]. Research on legacy, mainly industrial, hydrocarbon molecules in contaminated aquifers and pond systems has shown that chemical and biological reactions, typically involving bond cleavage affecting pollutant molecules, exhibit a specific isotope effect [34-38]. This generally results in the gradual change of stable isotope ratios of typical elements (e.g., ${ }^{2} \mathrm{H} /{ }^{1} \mathrm{H},{ }^{13} \mathrm{C} /{ }^{12} \mathrm{C},{ }^{15} \mathrm{~N} /{ }^{14} \mathrm{~N}$ and ${ }^{37} \mathrm{Cl} /{ }^{35} \mathrm{Cl}$ ) in organic pollutants during degradation or transformation, typically leading to an enrichment in the heavy isotope in the remaining parent compound [39]. This effect remains 
generally non-significant when non-degradative processes, such as sorption, dilution or volatilization, are involved. Hence, the average isotope value of the non-reacted fraction of the pollutant in environmental samples can be followed-up to evaluate the occurrence and the extent of degradation. It is worthy to note that isotope fractionation is also reactionspecific. Comparing changes of the stable isotope ratios of multiple elements (e.g., $\delta^{13} \mathrm{C}$ and $\left.\delta^{15} \mathrm{~N}\right)$ may thus serve to identify and distinguish transformation pathways of pollutants. While CSIA is today well-established for some legacy industrial compounds, pesticide CSIA is still emerging due to analytical challenges posed by low environmental concentrations (ng to $\mu \mathrm{g} \mathrm{L}^{-1}$ ) and compound polarity. Overall, pesticide CSIA bears the potential to distinguish and quantify biotic and abiotic transformation of pesticides, such as the herbicide S-metolachlor, in ponds compartments [34], in soils [40], soil lysimeters [41,42] or even at the catchment scale [43]. Stable isotope data should be optimally interpreted with physicochemical and hydrological tracer data to evaluate retention and transport processes in ponds $[44,45]$.

Special attention should also be paid to the fate of modern chiral pesticides and the transformation of their enantiomers in ponds (Figure 1B). Chiral pesticides, such as Smetolachlor, entail at least two enantiomers, which are non-superimposable mirror images of each other, and constitutes a significant portion of pesticides worldwide [46]. Although enantiomers of chiral pesticides have identical physico-chemical properties, they may display different toxicity levels. Knowledge of enantioselective degradation of chiral pesticides on the catchment scale is of increasing concern but remains very scarce [46,47]. It may be also valuable to combine enantiomer analysis of pesticides [48] with CSIA to jointly evaluate enantiomers and stable isotope fractionation of widely used fungicides, such as metalaxyl, as a result of stereoselective transformation by microorganisms [49]. Laboratory studies relying on enantiomers and/or isotope fractionation to evaluate biotransformation of chiral pesticides are currently scarce, with pond field studies missing so far.

3.1.2. Towards Potential Markers of Pesticide Biodegradation in Ponds Based on Degradation-Associated Taxa and Communities?

Regarding the relationship between microorganisms and pesticide dissipation in ponds, the subject of tolerance and adaptation of microbial communities to pesticides in the environment has not been given the same level of attention as that of pesticide degradation. Next-generation sequencing techniques relying on environmental DNA (eDNA) allows today to investigate the structure of macro- and micro-organisms populations and their response to individual or mixtures of pesticides $[29,50]$. In particular, comparative studies of protist, fungal and/or bacterial communities and their interplay may help to address microbial adaptation in agricultural pond receiving pesticides. Structural and functional characteristics of microbial communities represent potential indicators for monitoring the effects of pesticides in ponds and assessing their biological status. Although reference degrading strains are not available for most pesticides and functional genes for degradation are not known, approaches to identify bioindicators of toxicity based on bacterial community dynamics are emerging [51]. Exposure of bacterial compartments to pesticides can mediate adaptive responses of the pond microbial communities (Figure 1B). Those responses may in turn alter the composition and function of microbial communities [51] and eventually affect $\mathrm{C}, \mathrm{S}$ or $\mathrm{N}$ cycles in ponds [52].

It has rarely been explored how pesticides affect directly or indirectly the nitrogen cycle [53] and consequently the living biota in aquatic systems [54]. For example, chlorothalonil inhibited soil denitrification process in riparian sediment by deteriorating organic matter metabolism (electron production), electron respiration chain (electron transport) and denitrifying enzymes activities (electron utilization), more than by altering denitrifier communities or denitrifying gene abundances [55,56]. More generally, microbial interactions between pesticides and C, N, P cycles and co-metabolic degradation of pesticides may be largely underestimated in ponds and in integrative studies of agricultural catchments, where nitrogen loads by fertilizers inputs are significant. However, hydrologi- 
cal and hydrochemical fluctuations and vegetation development in ponds may mask the effects of pesticide exposure on overall bacterial community compositions [57].

Overall, there is a substantial potential and interest to examine with unprecedented sensitivity today the response of the pond's microbial communities exposed to pesticides. More fundamentally, the contribution and rates of oxidative and reductive pathways of pesticide transformation and the associated microbial diversity at the sediment-water interface are largely unknown.

\subsection{Understanding the Role of the Sediment-Water Interface in Pesticide Dissipation}

Processes sustaining pesticide sorption, settling with suspended particulate matter and degradation are manifold and interact with each other across biogeochemical gradients formed at the sediment-water interface (SWI) of ponds. Vertical gradients of light, temperature and oxygen concentrations affect biogeochemical conditions in both the water and the sediment compartments and control the pesticide behavior over depth (Figure 1A). Pesticide photodegradation prevails generally in the first centimeters of the water column in less vegetated ponds [44]. Hydrophobic pesticides $\left(\log \mathrm{K}_{\mathrm{ow}}>3\right)$ sorb onto suspended particles [6], and especially on finer particles [10]. Finer particles partly remain suspended in the water column or settle, depending on the water level and depth, hydrological dynamics and the vegetation [58].

The presence, diversity, density and patchiness of macrophytes in ponds control the SWI dynamics, and thus affect the transport and the dissipation of dissolved and solidbound pesticides. The vegetation controls the SWI dynamics directly by the release of rhizosphere carbonaceous exudates that enhance biofilm development and/or sorption. The vegetation also controls the SWI dynamics indirectly by slowing down water flow, increasing sedimentation rate of pesticides in the particulate phase [59] or reducing photolytic degradation by creating shaded zones. Heterotrophic biofilms exert a major influence on the biochemical transformation of pollutants [60]. Reductive processes sustained by the decomposition of vegetal organic matter may affect pollutant sorption with organic matter in the sediment, influence pesticide sorption onto particulate and dissolved organic matter in the water column and favor transformation under anoxic conditions [61,62]. Overall, ponds enhance sedimentation while upstream particulate matter is regularly deposited on the surface layers of bottom sediment, altering sediment physico-chemical properties and biogeochemical processes of the SWI [63]. The fine sediments and associated pesticides can be mobilized during flood events and exported from the pond following a storage phase in the bottom sediment under low flow conditions [63,64].

Despite the dynamic character of the SWI, pesticide behavior at the SWI of ponds has been mainly studied under static conditions [65]. In particular, the overlying water velocity is recognized as a critical factor controlling the chemical distribution across the SWI, and thus pesticide degradation across biogeochemical gradients formed at the SWI [66]. New concepts and approaches, including high-resolution and less-invasive sampling, pesticide CSIA and modelling accounting for sediment redox zonation and diagenesis (Figure 1C), are required to evaluate and predict pesticide transformation at the SWI of ponds. Modelling the SWI of ponds integrating transient storm events is numerically challenging, although recent advances have been made to predict pesticide behavior at the SWI $[67,68]$. Most importantly, SWI modelling of ponds requires to integrate both biotic and abiotic reactive transport processes. Specific emphasis should be placed on the contribution of biodegradation, as it mainly contributes to mass depletion of pesticides and the formation of transformation products.

Yet the relationship between pesticide dissipation at the SWI and pond scales and pesticide transfer at the catchment scale is not well-established. We explore below this issue by sketching a modelling framework integrating the role of pond in pesticide dissipation at catchment scale. This framework addresses processes simplification from the pond to the headwater catchment, and from the headwater catchment to the larger river basin scales (Figure 2). 


\section{Towards a Framework Integrating the Role of Ponds at the Catchment Scale}

An integrated modelling approach predicting pesticide transfer in agricultural basins should include spatially distributed land use and agricultural management practices, soil characteristics and hydro-climatic conditions, upstream transfer risks (Figure 1D) and dissipation processes in ponds (Figure 1C). Such an integrated approach remains scarce and concerns mainly the pond hydrological dynamics [69] or the dissipation efficiency of macro-pollutants, such as nitrogen or phosphorus [70,71].

Pesticide dissipation processes implemented in agro-hydrological models are very often not specific to ponds. For example, existing modelling approaches at the SWI scale such as PCPF-1 [72] focus on pesticide behavior in paddy fields. Small ponds and large lakes are considered at the catchment scale using similar procedures and equations in the Soil and Water Assessment Tool (SWAT) model [24,73] (Figure 2). In addition, the ability of buffering objects to dissipate pollutants is addressed without any validation steps. This is mainly due to the discrepancy between the availability of consistent datasets and the modelling requirements, which increases the uncertainties of pesticide transfer predictions at the catchment scale.

In this context, we propose an integrated modelling framework in the five steps described in Figure 1 and Tables 1 and 2. The framework covers four nested scales, from the SWI of ponds up to the river basin (Figure 2). 


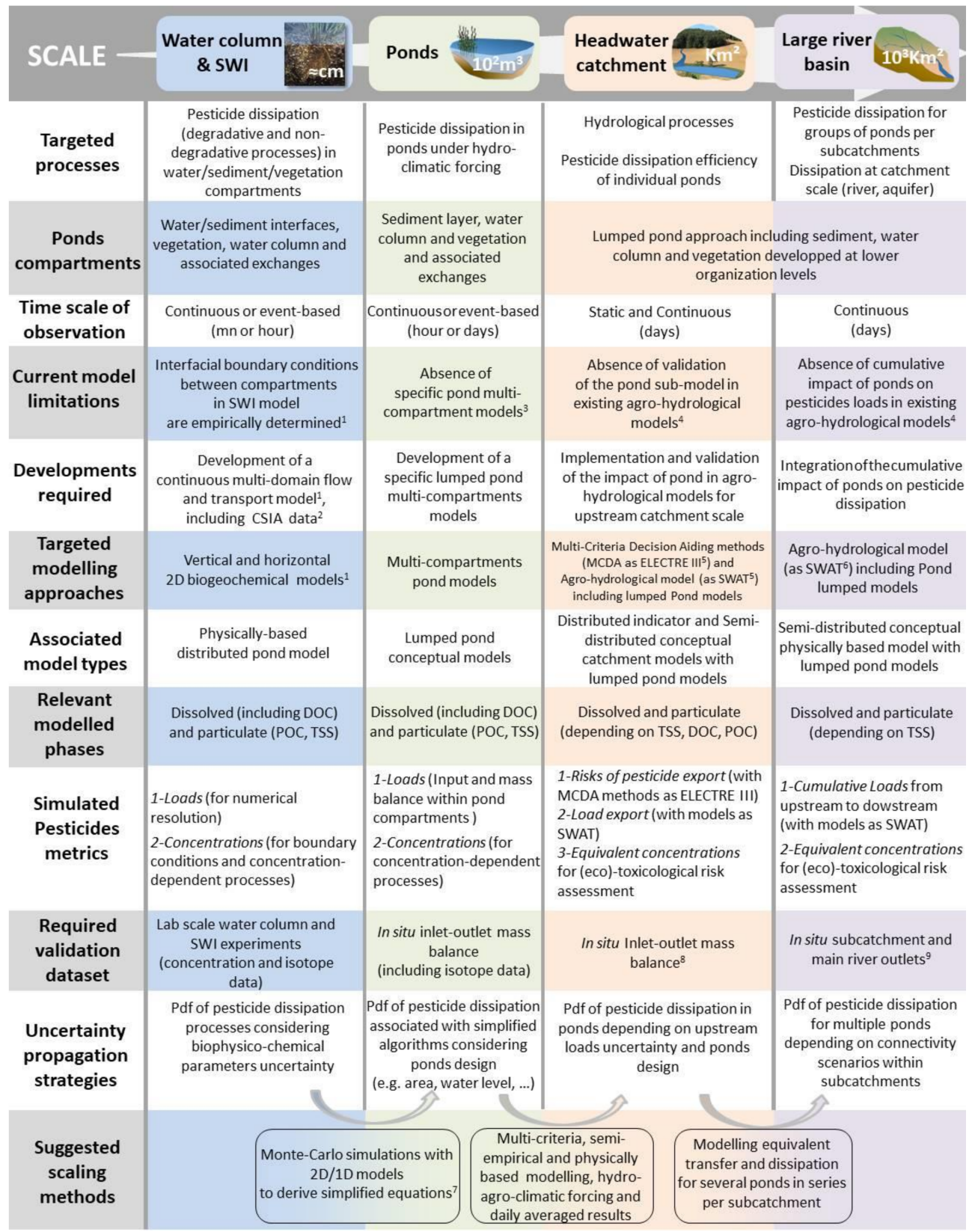

Figure 2. Modelling framework integrating the role of ponds to control pesticide transfer at the headwater catchment and the large river basin scales. The framework involves a modelling chain from pesticide dissipation within pond compartments up to pesticide transfer in river basins. Pdf: probability density function. ${ }^{1}$ Based on Stokes-Darcy-Brinkman conceptualization [74]; ${ }^{2}$ Reactive transport (e.g., [43]); ${ }^{3}$ Multi-compartment models [72]; ${ }^{4}$ Adapting the behavior of pesticide and ponds compartments in SWAT [75], with empirical relationships (0D modelling) derived from the results of the 2D models at the pond scale. The 0D modelling attributes a dissipation rate to each pesticide, depending on the measurable variables and the ponds' characteristics and connectivity; ${ }^{5}$ [76-78]. ${ }^{6}$ [75]; ${ }^{7}$ following the approach developed by [79]; ${ }^{8}$ A detailed mass balance can be performed from the existing databases to identify the optimal formalisms and provide a diagnosis with existing data from upstream catchment and ponds. Datasets are obtained from the well-referred experimental sites of the PESTIPOND project (Figure S1 and Table S1 of the Supplementary Materials). The PESTIPOND experimental sites belong to the RI-OZCAR (Research Infrastructure-Critical Zone Observatories: Research and Application [80]), the RECOTOX network (Research initiative in toxicology/ecotoxicology [81]), the RI-RZA (LTSER Zones Ateliers network [82]), and/or the European RI-eLTER (European Long-Term Ecosystem Research). ${ }^{9}$ Monitored river-basin such as the Save (Site of the LTSER Zone Atelier Pyrénées-Garonne, Gascony, $1100 \mathrm{~km}^{2}$ ) $[77,83,84]$ can support the development and the validation of the last upscaling step of impact of ponds from the headwater catchments to the large river basins. 


\subsection{Step 1: Evaluating Pesticide Dissipation in Ponds with 2D Models}

Mechanistic models allow the dynamic simulation of pesticide dissipation in relevant compartments of ponds as a function of the hydraulic residence time, hydraulic efficiency [85], water depth, vegetation growth and pesticide partitioning in the inlet of ponds (dissolved and particulate). Relevant functional compartments of ponds include surface water, the SWI, the plant/water and the sediment/plant interfaces. 3D computational fluid dynamics (CFD) models incorporating these compartments may require excessive calculation time [86]. However, the diversity of existing ponds geometry justifies an explicit description of the spatial variability of ponds using both horizontal and vertical 2D approaches. The 2D modelling approaches can improve predictions of the dynamics of water pathways, transit times in relation to biogeochemical processes and pesticide dissipation (Table 1).

In particular, the horizontal 2D $(x, y)$ modelling approaches are useful to include explicitly the vegetation patches and to estimate the water pathways and their transit times in ponds [68]. A pseudo 3D model could be obtained by coupling the 2D modelling approaches with the horizontal dimension for the hydraulic step and the vertical dimension for the biogeochemical step (Figure 1C).

The 2D horizontal modelling approach integrates the system geometry [87] and the vegetation patches under steady-state conditions [88]. The vegetation patches can be represented as equivalent porous medias, with porosity and conductivities properties, to provide hydraulic efficiency characteristics including shortcuts, dead-zones and speed fields [89]. The vertical 2D (x,z) approach can describe explicitly stratification of biological, chemical and physical processes at the SWI [89] and their impact on pesticide dissipation for systems with a simplified geometry (Figure 1C). Such an approach has been recently developed for phosphorus mitigation in constructed wetlands [90].

A sub-daily time step should be used to represent accurately hydraulic dynamics and pesticide distribution in pond compartments during high-flow events. This requires data of inlet pesticide concentrations acquired at high temporal resolution, which is generally missing, to feed into the pond model. In addition, pesticide dissipation and pesticide export from the ponds should be examined under both low-flow conditions between hydroperiods (i.e., the portion of year the system holds ponded water), and high flow conditions during transient hydroperiod.

\subsection{Step 2: Considering Pesticide Dissipation in Ponds during and between Hydroperiods}

During dry periods, i.e., without significant water discharges entering into ponds, modelling approaches may integrate biogeochemically-relevant compartments, including the overlying water, the SWI and the sediment and processes typically observed under static conditions. Pesticide dissipation processes, major biogeochemical cycles (C, N and S) and physico-chemical parameters (e.g., $\mathrm{pH}$, temperature, dissolved oxygen content) influencing the biogeochemical stratification in the water column and the sediment can be included in a 2D vertical SWI model, such as the 2D SWI model developed for marine sediment [91].

Sediment is a key compartment for pesticide sorption, in particular between hydroperiods. Sorption depends on the nature and amount of minerals and organic matter forming the sediment, including decaying vegetation and involving macrophyte stems and biofilms. Sorption onto sediment may store pesticides temporarily only. Indeed, desorption and subsequent remobilization of pesticides from the sediment to the water column may occur, depending on the pesticide properties and abiotic factors, including the water physicochemical conditions and the flow velocity. Linear or Freundlich sorption isotherms are used classically to represent pesticide sorption in ponds. However, conceptualizing sorption and desorption remains challenging and depends on pesticide partitioning coefficient values $\left(\mathrm{K}_{\mathrm{d}}\right)$. For instance, Passeport et al. [19] showed experimentally for different pond sediments that sorption of pesticides with low $\mathrm{K}_{\mathrm{d}}$ values is similar to that of desorption for silty clay loam and $\mathrm{pH} 6.5$ to 8.5 . In contrast, desorption of pesticides with intermediate or higher $\mathrm{K}_{\mathrm{d}}$ values may be neglected as sorption is much faster than desorption. To discriminate pesti- 
cide degradation from sorption or dilution in ponds, coupling numerical modelling with compound-specific isotope analysis (CSIA) (Figure 1B) may be helpful [92,93]. In particular, incorporating CSIA data in numerical models could help in reducing the equifinality issues and thus increase the accuracy of estimations of pesticide dissipation in ponds [94,95].

During hydroperiods, modelling the dynamics of large and varying inlet discharges in relation to hydraulic characteristics of ponds, including their residential time and hydraulic efficiency, is difficult. The Stokes-Darcy-Brinkman equation $[27,89,96]$ can be adopted for both the $2 \mathrm{D}$ vertical and horizontal discretizations to predict pesticide reactive transport (Figure $1 \mathrm{C}$ and Table 1). This equation considers reactive transport across the water column-SWI-sediment layer continuum without discontinuity of numerical schemes at compartment interfaces (Figure 1C and Table 1). The Stokes-Darcy-Brinkman conceptualization may also incorporate vegetation as a porous media in models conceived at the pond scale [74]. Reactive transport model for ponds during high-flow conditions can be designed by combining conceptual scheme developed under dry period conditions and the Stokes-Darcy-Brinkman equation including dissolved and particulate pesticide transport. Upscaling approaches of pesticide dissipation from the pond to the headwater catchment scales could then be defined. For instance, empirical relationships can be derived from these 2D physically-based models to calculate residence time functions [44] from pond geometry and inflow-outflow dynamic and to include biogeochemical processes at the SWI [79] (Table 1) and improve existing modules for ponds in agro-hydrological models [26] (Table 2).

\subsection{Step 3: Deriving Simplified Ponds Models for Implementation at Catchment Scale}

A preliminary step to derive simplified ponds models for further implementation at catchment scale is to develop empirical relationships using e.g., Monte-Carlo simulations summarizing results of the 2D models (Figure 1C, Table 1). These relationships can be included in a new lumped module within an agro-hydrological model. Such simplified modules can then provide efficiencies of pesticides dissipation in ponds as a function of parameters available at the headwater catchment scale, including pond geometry, vegetation density, pesticide properties, climatic variables and upstream runoff, sediment and pesticides fluxes simulated by agro-hydrological models (Table 2).

A similar approach of empirical relationship was successfully developed by Billen et al. [79] to predict benthic nutrient fluxes. In addition, and most importantly, Monte-Carlo simulations can be used to determine confidence intervals $(\mathrm{CI})$ and probability density functions (pdf) associated with pesticide dissipation estimates in ponds (Figure 2). The pdf of pesticide dissipation estimates obtained using such module can then be used to propagate the uncertainty associated with pesticide dissipation at the catchment and river-basin scales when ponds are included.

\subsection{Step 4: Adapting Agro-Hydrological Models to Integrate the Role of Ponds}

The role of "off-fields" buffer objects, such as grass strips, vegetated ditches, riparian zones and ponds or dams, in mitigating runoff, erosion and associated nutrients and pesticides fluxes is only partly accounted for in current agro-hydrological models [24,97,98]. This is because (i) the calibration and the evaluation of their buffering effect remains delicate, (ii) consistent datasets are generally missing and (iii) current agro-hydrological models require adaptation. Comprehensive catchment models, such as SWAT [99], cover a wide range of processes for representing relevant hydrological and pesticide related processes [100]. Among 36 widely used pesticide models [101], SWAT may be particularly well-suited for modelling pesticide reactive transport under a wide variety of conditions [100]. Such agro-hydrological models can be used to estimate at the basin scale the risk of pesticide transfer including the contribution of pond, while improving predictions in a context of global change [102].

As an example and to illustrate a model adaptation to integrate the role of pond at the catchment scale, the PESTIPOND project is developing a new module. This lumped OD 
module integrates at a daily time step the processes associated with pesticide dissipation at the SWI and the water column in each pond using simplified multi-parameters and multi-compartments formalisms (see Section 3.1., Figure 1C and Table 2). Model calibration and validation is a critical step that strongly depends on the data series obtained at the pond and at the catchment scales under various hydrological conditions (Figure 1A). To address the changes of organizational level (Figure 2), the SWAT model integrating the new pond lumped module (Tables 1 and 2) will be implemented first at the scale of the Auradé catchment $(28 \mathrm{Ha})$ as a sub-catchment of the Save river basin $\left(1100 \mathrm{~km}^{2}\right)$, and before upscaling at the whole Save river basin (see SI for a description of Auradé catchment). Pesticide transfer can then be related to factors controlling pesticide dissipation in the dissolved and the particulate phases including the residence time, organic matter content, sediment or the pond structure. Model calibration and validation rely on fluxes of both dissolved and solid-bound pesticides (Figure 2) monitored under both low- and high-flow conditions for two years $[8,83,84]$.

To integrate the cumulative effect of successive ponds in pesticide dissipation at the river basin scale (Figure 1D), one option is to create a sub-basin at the outlet of each pond. This sub-basin could integrate upstream hydrological processes, sources and transfer of pesticides (Table 1) into each pond, along with pond processes. Alternatively, virtual ponds representing the effect of cumulative ponds and a sub-basin related to the cumulative effect could be created. However, pesticide transfer from agricultural plots into ponds should be accounted for to improve predictions at the river-basin scale.

\subsection{Step 5: Modelling Pesticide Transfer from Fields to Ponds at the River-Basin Scale}

With changes of organizational level from the headwater catchment scale (i.e., from ha to dozen of $\mathrm{km}^{2}$ ) to the river-basin scale (i.e., from dozen to thousands of $\mathrm{km}^{2}$ ), the predictive capacity of the model to account for pesticide transfer towards ponds should be preserved. Extrapolation of processes across scales requires simplifying processes while losing a minimal amount of information or processes across scales.

From a qualitative viewpoint, Multi-Criteria Decision Aiding (MCDA) methods, such as ELECTRE III and Tri_C models, can be coupled to GIS to evaluate pesticide transfer risks from agricultural fields to pond at the headwater catchment scale (Figure 2) and to assess agro-environmental risks of water surface contamination (Figure 1D) $[77,78,103]$. MCDA are complementary to semi-distributed agro-hydrological models (Figure 1D), such as SWAT $[8,23,75,83]$. The combination of MCDA and semi-distributed agro-hydrological models have the potential to integrate current and potential risks of pesticide transfer in a context of climate change, accounting for the pesticide applications, crops rotation, matter transport and upstream-downstream hydrological connectivity. This approach has been used already to evaluate daily nitrate loads [104] and pesticide transfer in the $1100 \mathrm{~km}^{2}$ Save river-basin [8,77]. A specific feature of the MCDA method is that it integrates both qualitative and quantitative criteria that cannot be considered otherwise in agro-hydrological models. This includes pesticide inputs, land use and agricultural management practices, but also best management practices, such as filter strips and riparian zones, soil characteristics and slopes, and the nature of hydrological pathways from each farming parcels towards surface waters $[77,103,105]$ that control inputs of dissolved and particulate-laden pesticides towards ponds. The MCDA method has been applied previously to evaluate erosion, nitrate and pesticide transfer in different areas and farming systems [103,105,106].

From a quantitative viewpoint, current agro-hydrological models can be used to simulate the transfer of suspended sediments and associated nutrients $(C, N, P)[8,23]$. Few models are able to simulate pesticide transfer in relation to hydro-climatic conditions and hydrological processes $[12,83,107]$. This is of fundamental relevance as the dominant hydrological processes controlling pesticide transfer from agricultural plots to ponds are surface runoff, lateral subsurface flow and tile drainage flow (e.g., [77,105], Table 1). In particular, seasonal factors, such as pesticide application, tillage practices, wet-dry cycles, flood events are crucial to determine and predict the role of ponds on pesticide dynamics [14]. 


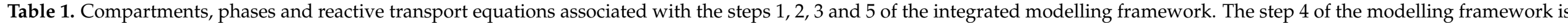
detailed in the Table 2.

\begin{tabular}{|c|c|c|c|}
\hline & $\begin{array}{c}\text { Step 2: } \\
\text { Considering Pesticide } \\
\text { Dissipation in Ponds during } \\
\text { and between Hydroperiods } \\
\text { with 2D Models [89,108] }\end{array}$ & $\begin{array}{c}\text { Step 3: } \\
\text { Deriving Simplified Ponds Models for } \\
\text { Implementation at Catchment Scale with } \\
\text { 2D Model Monte Carlo Runs }\end{array}$ & $\begin{array}{c}\text { Step 5: } \\
\text { Modelling Pesticide Transfer } \\
\text { from the Fields to the Ponds at } \\
\text { the River-Basin Scale with } \\
\text { SWAT }[100,109]\end{array}$ \\
\hline Phases & Dissolved and particulate & Dissolved and particulate & Dissolved and Particulate \\
\hline Water mass balance & $\begin{array}{l}S_{1} \cdot \frac{\rho}{\epsilon} \cdot \frac{\partial u}{\partial t}+S_{2} \cdot \frac{\mu}{R} \cdot u+S_{3} \cdot \frac{\rho}{\epsilon^{2}} \cdot(u \cdot \nabla) \cdot u-S_{4} \cdot \frac{\mu}{\epsilon} \cdot \nabla \cdot(\nabla u)+ \\
\nabla P=-\rho \cdot g \cdot \nabla z \\
\nabla \cdot u=0\end{array}$ & $\begin{array}{l}\text { Pond Hydraulic Retention Time }(\mathrm{HRT})= \\
\text { f(pond geometry ranges [lengh, width, depth, } \\
\text { shortcuts, dead-zones], vegetation patches, and } \\
\text { inflow) }\end{array}$ & $\begin{array}{l}\text { Rainfall, Infiltration, Evapotranspiration } \\
\text { Percolation, Runoff, Lateral sub-surface flow, Capillary } \\
\text { fringe, River/aquifer exchanges, soil erosion for both } \\
\text { pond upstream and dowstream }\end{array}$ \\
\hline Physico-chemical process rates & $\begin{array}{l}\epsilon \cdot \frac{\partial C_{i}}{\partial t}+\rho_{\text {bulk }} \cdot \frac{\partial S_{i}}{\partial t}+u \cdot \nabla C_{i}-\nabla \cdot\left(D_{i} \cdot \nabla C_{i}\right)=r_{i} \\
D_{i}=D_{m, i} \cdot I+D_{d i s p}= \\
\left(\alpha_{T} \cdot|u|+D_{m}\right) \cdot \delta_{l m}+\left(\alpha_{L}-\alpha_{T}\right) \cdot \frac{u_{l} \cdot u_{m}}{|u|} \quad l, m=1,2 \\
\frac{\partial S_{i}}{\partial t}=\alpha_{i} \cdot\left(K_{d, i} \cdot C_{i}-S_{i}\right)\end{array}$ & \multirow{2}{*}{$\begin{array}{l}\text { Pesticides partitioning between dissolved particulate, } \\
\text { sediment and TOC phases and biofilm on vegetation } \\
\text { and sediment = } \\
\text { f(range of pond HRT, TSS, DOC, sediment range in } \\
\text { inflow and physico-chemical properties of targeted } \\
\text { pesticides, vegetation types and density)Pesticides } \\
\text { degradation* }= \\
\text { f(range of HRT, TSS, DOC, Oxygen consumption in } \\
\text { sediment and physico-chemical properties of targeted } \\
\text { pesticides) } \\
{ }^{*} \text { including biodegradation, direct and indirect photolysis } \\
\text { and hydrolysis }\end{array}$} & \multirow{2}{*}{$\begin{array}{l}\text { - Between interstitial water and soil particles } \\
\text { - Field scale degradation with a lumped half-life } \\
\text { integrating volatilization, photolysis, hydrolysis and } \\
\text { biodegradation } \\
\text { - Transport from fields to rivers by soil water fluxes } \\
\text { (surface runoff, lateral flow and percolation) in } \\
\text { dissolved and particulate phases } \\
\text { - In-stream process including degradation, } \\
\text { volatilization, settling, diffusion and burial. }\end{array}$} \\
\hline $\begin{array}{l}\text { Biological process rates } \\
\text { (Michaelis- Menten) }\end{array}$ & $\begin{array}{l}\text { Oxygen consumption in sediment } \\
\frac{d\left[\mathrm{O}_{2}\right]}{d t}=k_{\mathrm{O}_{2}} \cdot\left[o_{2}\right] \\
\text { Oxygen controlled degradation } \\
k_{\text {oxic }}=k_{\text {max }} \text { oxic } \cdot \frac{\left[\mathrm{O}_{2}\right]}{\left[\mathrm{O}_{2}\right]+K_{M}} \\
\frac{d[\text { pesticide }]}{d t}=k_{\text {oxic }} \cdot[\text { pesticide }] \\
\text { Modelling of stable isotope fractionation (e.g., carbon): } \\
k^{13 C}=\left(1+\epsilon_{\mathrm{C}}\right) \cdot k^{12 C}\end{array}$ & & \\
\hline Variables and parameters & \multicolumn{3}{|c|}{ 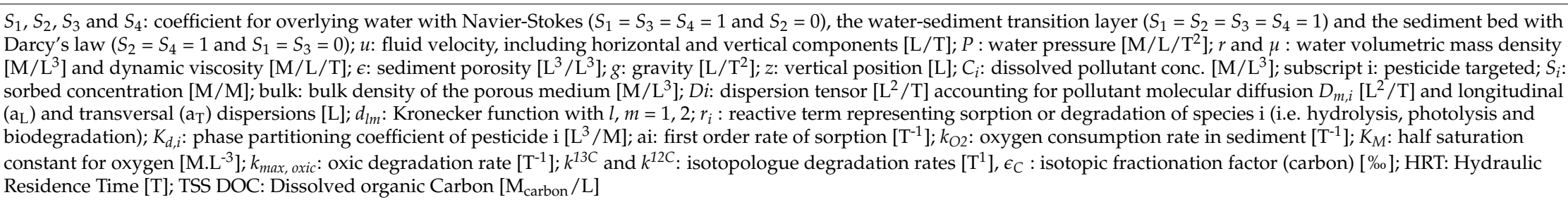 } \\
\hline Compounds used for validation & $\begin{array}{l}\mathrm{NaCl} \text { and Foron Blue } 91 \text { used as conservative and sorptive tracers, } \\
\text { respectively, and caffeine as a degradative organic compound }\end{array}$ & $\begin{array}{l}\text { Validation with data from well-referred experimental } \\
\text { sites of the PESTIPOND project (see } \\
\text { Supplementary Materials) }\end{array}$ & 33 different pesticides at the catchment scale \\
\hline
\end{tabular}


Table 2. Lumped models for pesticide dissipation in wetlands, lakes or paddy fields. The lumped models could be adapted to predict pesticide dissipation in ponds.

\begin{tabular}{|c|c|c|c|c|}
\hline & PCPF-1 [72] & AGRO-2014 [110] & SWAT $[109,111]$ & Tank-in-Series TIS [22] \\
\hline Compartments & $\begin{array}{l}\text { Paddy water } \\
\text { Paddy surface soil layer }(1 \mathrm{~cm})\end{array}$ & $\begin{array}{l}\text { Water column, Total suspended solids } \\
\text { (TSS), } \\
\text { Pore-water, Sediment }\end{array}$ & Water, vegetation, soil, aquifer, river & Water \\
\hline Phases & $\begin{array}{l}\text { No distinction between the dissolved } \\
\text { and particulate phases }\end{array}$ & Dissolved and particulate & Dissolved and particulate & $\begin{array}{l}\text { No distinction between the dissolved } \\
\text { and particulate phases }\end{array}$ \\
\hline Water mass balance & $\begin{array}{l}\frac{d h_{w}}{d t}=\text { Rain - Irrig.- } \\
\text { Drainage - Percol. - Evapotransp. }\end{array}$ & Constant water volume & $\begin{array}{l}V_{w, t} \\
=V_{0} \\
+\sum_{\text {Rain }}-\text { runoff } \\
\left.- \text { Evapotransp. }-w_{\text {seep }}-Q_{\text {outflow }}\right)\end{array}$ & $\frac{d V_{w}}{d t}=r u n o f f_{\text {inlet }}-r u n o f f_{\text {outlet }}$ \\
\hline $\begin{array}{l}\text { Physico-chemical process rates } \\
\text { (1st order model) }\end{array}$ & $\begin{array}{l}\text { Desorption: } k_{d e s} \cdot \frac{d_{S}}{h_{W}} \rho_{b} \\
\text { Photolysis: } k_{\text {photo }} \cdot \frac{d E_{U V B-C}}{d t}\end{array}$ & \multirow{2}{*}{$\begin{array}{l}\text { Volatilization: } \frac{S_{w} \cdot E V P}{V_{W}} \\
\text { Settling: } \frac{S_{w} \cdot v_{s}}{V_{w}} \\
\text { Resuspension: } \frac{v_{r}}{v_{s}} \\
\text { Lumped degradation rates:* } \\
\text { Water: } \frac{\ln (2)}{D T_{50, w}} \\
\text { Sediment: } \frac{\ln (2)}{D T_{50, s}} \\
\text { * Biodegradation, photolysis and hydrolysis }^{*}\end{array}$} & $\begin{array}{l}\text { Volatilization: } v_{v} * \frac{1}{h_{W}} \\
\text { Settling: } \frac{S_{w} \cdot v_{s}}{V_{w}} \\
\text { Sorption: } C s=K_{d} * C w \\
\text { Resuspension: } \frac{v_{r}}{d_{s}}\end{array}$ & \multirow{2}{*}{$\begin{array}{l}\text { One parameter } \mathrm{k} \text { describes the pesticide } \\
\text { decay between the inlet and outlet of the } \\
\text { wetland at each tank } \\
\frac{\text { Cout }_{\text {ont }}}{C_{\text {in,tank }}}=\exp (-k t)\end{array}$} \\
\hline $\begin{array}{l}\text { Biological processes rates } \\
\text { (1st order model) }\end{array}$ & $\begin{array}{l}\text { Biodegradation: } \\
\text { Water: } \frac{\ln (2)}{D T_{50, w}} \\
\text { Sediment: } \frac{\ln (2)}{D T_{50, s}}\end{array}$ & & $\begin{array}{l}\text { Lumped degradation rates: } \\
\text { Water: } \frac{\ln (2)}{D T_{50, w}} \\
\text { Sediment: } \frac{\ln (2)}{D T_{50, s}} \\
\text { * Biodegradation, photolysis and hydrolysis }\end{array}$ & \\
\hline $\begin{array}{c}\text { Description of variables and } \\
\text { parameters }\end{array}$ & \multicolumn{4}{|c|}{$\begin{array}{l}w_{\text {seep }}: \text { water entering the vadose zone from the soil profile; } Q_{o u f f l o w}: \text { pond outflow; } C_{w}: \text { Pesticide concentration in water; } C_{s}: \text { Pesticide concentration in the sediments; } k_{d e s}: \\
\text { First-order rate constant for pesticide desorption from the sediment surface; } d_{s:} \text { Depth of the sediment layer; } h_{w:} \text { Water depth; } S_{w:} \text { Water surface area; } V_{w:} \text { Water volume; } \rho_{b:} \text { : } \\
\text { Bulk density of the sediment layer; } k_{p h o t o}: \text { First-order rate coefficient of photochemical degradation with respect to the cumulative UV-B radiation as measured in laboratory } \\
\text { conditions; } E_{u V B-c}: \text { Cumulative UV-B radiation }\left(\mathrm{kJM}^{-2}\right) ; E V P: \text { Evaporation rate; } D T_{50, s}: \text { Half-life in sediments; } D T_{50, w}: \text { Half-life in water; } k_{v}: \text { First-order rate constant for } \\
\text { pesticide volatilization in water; } v_{s}: \text { Settling velocity; } v_{r}: \text { Resuspension velocity; } K_{d}: \text { Sediment-water partition coefficient, HRT: pond Hydraulic Residence Time. }\end{array}$} \\
\hline Pesticides used for validation & $\begin{array}{l}\text { Mefenacet, Pretilachlor, } \\
\text { Bensufuronmethyl }\end{array}$ & $\begin{array}{l}\text { Metaflumizone, Kresoxim-methyl, } \\
\text { Pyraclostrobin }\end{array}$ & Chlorpyrifos, Diazinon & Diazinon, Methomyl, Acephate \\
\hline
\end{tabular}




\section{Conclusions}

The role of ponds to control pesticide transfer in interlocked scales from the headwater catchment to the river basin remains largely unexplored. This review emphasizes that processes associated with pesticide transfer, storage and transformation in ponds compartments should be thoroughly evaluated in relation to pesticide transfer at the catchment scale. Pesticide dissipation in pond and pesticide transfer at the catchment scale are commonly treated separately, limiting accurate prediction of pesticide transfer and related operations at the catchment scale. We believe that considering the role of ponds at the catchment scale can help improving the prediction and the operational control of the downstream pesticide transfer in the agricultural landscape. However, several issues need to be addressed in order to understand, follow-up and predict the role of ponds in limiting pesticide transfer at the catchment scale.

Regarding the functional processes underpinning pesticide storage and transformation in ponds, a major research direction is to develop concept and approach to distinguish the contribution of degradative and non-degradative processes in ponds. In particular, the direct and indirect role of microorganisms associated with pesticide degradation processes is poorly understood currently. Most importantly, a fundamental effort is required to followup and predict the interplay of physico-chemical, hydrological and biological processes at the sediment-water interface of ponds and its role for pesticide dissipation.

Concerning the development of an integrative modelling framework of pesticide transfer at the catchment scale including the role of ponds, this review underscores two issues that have not been answered yet. First, it is required to improve the implementation and parametrization of pesticide dissipation from the sediment-water interface of the pond, and from the pond or a set of ponds up to the catchment and the river-basin. Second, specific attention should be paid to consolidate conceptual simplifications of pesticide dissipation across scales.

The integrative modelling framework sketched here in five steps is expected to deliver currently poorly accessible knowledge on hydrological and biogeochemical processes at the pond scale. Such knowledge can be incorporated into models across scales to connect the pond functioning with the dynamics of the headwater catchment. An additional feature of the proposed modelling framework is that it can be used to co-construct with socioeconomic actors scenarios of pond structure, functioning, location or management. These scenarios can help to formulate new guidelines to optimize pesticide dissipation of ponds under various land uses and agricultural practices in a context of global changes. This includes managing existing ponds, existing either as individual or successive entities, and integrate them into the landscape to consider their impact on water quality.

Supplementary Materials: The following are available online at https:/ /www.mdpi.com/article/10 $.3390 / w 13091202 / s 1$. Figure S1, Location of the PESTIPOND experimental sites and mean yearly concentration of pesticides in surface water (adapted from Agences et offices de l'eau. Traitements: SOeS, 2015). Table S1, PESTIPOND experimental sites.

Author Contributions: Conceptualization, G.I., S.P., J.T., S.S., F.M. and J.-L.P.; writing—original draft preparation, G.I.; writing—review and editing, S.P., J.T., S.S., F.M., C.C., A.B., J.-M.S.-P., A.P., B.C., H.A., T.G. and J.-L.P.; project coordination, G.I. All authors have read and agreed to the published version of the manuscript.

Funding: The study was funded by the French National research Agency ANR through grant ANR-18-CE32-0007, project PESTIPOND.

Institutional Review Board Statement: Not applicable.

Informed Consent Statement: Not applicable.

Data Availability Statement: This study does not report any data.

Acknowledgments: We wish to thank Richard Coupe (USGS) for helpful discussion and proofreading the manuscript. 
Conflicts of Interest: The authors declare no conflict of interest. The funders had no role in the design of the study; in the collection, analyses, or interpretation of data; in the writing of the manuscript, or in the decision to publish the results.

\section{References}

1. Sharma, A.; Kumar, V.; Shahzad, B.; Tanveer, M.; Sidhu, G.P.S.; Handa, N.; Kohli, S.K.; Yadav, P.; Bali, A.S.; Parihar, R.D.; et al. Worldwide pesticide usage and its impacts on ecosystem. SN Appl. Sci. 2019, 1, 1446. [CrossRef]

2. Implementation of Directive 2009/128/EC on the Sustainable Use of Pesticides. Available online: https: / / www.europarl.europa. eu/doceo/document/A-8-2019-0045_EN.html (accessed on 5 February 2020).

3. Fenner, K.; Canonica, S.; Wackett, L.P.; Elsner, M. Evaluating Pesticide Degradation in the Environment: Blind Spots and Emerging Opportunities. Science 2013, 341, 752-758. [CrossRef] [PubMed]

4. Azzi, E.D.; Probst, J.-L.; Teisserenc, R.; Merlina, G.; Baqué, D.; Julien, F.; Payre-Suc, V.; Guiresse, A.M. Trace Element and Pesticide Dynamics During a Flood Event in the Save Agricultural Watershed: Soil-River Transfer Pathways and Controlling Factors. Water Air Soil Pollut. 2016, 227, 442. [CrossRef]

5. Rabiet, M.; Margoum, C.; Gouy, V.; Carluer, N.; Coquery, M. Assessing pesticide concentrations and fluxes in the stream of a small vineyard catchment-Effect of sampling frequency. Environ. Pollut. 2010, 158, 737-748. [CrossRef]

6. Taghavi, L.; Probst, J.-L.; Merlina, G.; Marchand, A.-L.; Durbe, G.; Probst, A. Flood event impact on pesticide transfer in a small agricultural catchment (Montoussé at Auradé, south west France). Int. J. Environ. Anal. Chem. 2010, 90, 390-405. [CrossRef]

7. CGDD (Commissariat Général Au Développement Durable), Note N697. Available online: https:/ / www.actu-environnement. $\mathrm{com} /$ media/pdf/news-25719-chiffres-pesticides-cours-eau.pdf (accessed on 5 February 2020).

8. Boithias, L.; Sauvage, S.; Merlina, G.; Jean, S.; Probst, J.-L.; Pérez, J.M.S. New insight into pesticide partition coefficient Kd for modelling pesticide fluvial transport: Application to an agricultural catchment in south-western France. Chemosphere 2014, 99, 134-142. [CrossRef]

9. Grégoire, C.; Elsaesser, D.; Huguenot, D.; Lange, J.; Lebeau, T.; Merli, A.; Mose, R.; Passeport, E.; Payraudeau, S.; Schütz, T.; et al. Mitigation of agricultural nonpoint-source pesticide pollution in artificial wetland ecosystems. Environ. Chem. Lett. 2008, 7, 205-231. [CrossRef]

10. Maillard, E.; Imfeld, G. Pesticide Mass Budget in a Stormwater Wetland. Environ. Sci. Technol. 2014, 48, 8603-8611. [CrossRef] [PubMed]

11. Passeport, E.; Tournebize, J.; Chaumont, C.; Guenne, A.; Coquet, Y. Pesticide contamination interception strategy and removal efficiency in forest buffer and artificial wetland in a tile-drained agricultural watershed. Chemosphere 2013, 91, 1289-1296. [CrossRef] [PubMed]

12. Payraudeau, S.; Gregoire, C. Modelling pesticides transfer to surface water at the catchment scale: A multi-criteria analysis. Agron. Sustain. Dev. 2011, 32, 479-500. [CrossRef]

13. Stehle, S.; Elsaesser, D.; Grégoire, C.; Imfeld, G.; Niehaus, E.; Passeport, E.; Payraudeau, S.; Schäfer, R.B.; Tournebize, J.; Schulz, R. Pesticide Risk Mitigation by Vegetated Treatment Systems: A Meta-Analysis. J. Environ. Qual. 2011, 40, 1068-1080. [CrossRef] [PubMed]

14. Biggs, J.; Williams, P.; Whitfield, M.; Nicolet, P.; Weatherby, A. 15 years of pond assessment in Britain: Results and lessons learned from the work of Pond Conservation. Aquat. Conserv. Mar. Freshw. Ecosyst. 2005, 15, 693-714. [CrossRef]

15. Tournebize, J.; Chaumont, C.; Mander, Ü. Implications for constructed wetlands to mitigate nitrate and pesticide pollution in agricultural drained watersheds. Ecol. Eng. 2017, 103, 415-425. [CrossRef]

16. Locke, M.; Weaver, M.; Zablotowicz, R.; Steinriede, R.; Bryson, C.; Cullum, R. Constructed wetlands as a component of the agricultural landscape: Mitigation of herbicides in simulated runoff from upland drainage areas. Chemosphere 2011, 83, 1532-1538. [CrossRef]

17. Imfeld, G.; Braeckevelt, M.; Kuschk, P.; Richnow, H.H. Monitoring and assessing processes of organic chemicals removal in constructed wetlands. Chemosphere 2009, 74, 349-362. [CrossRef]

18. Vymazal, J.; Březinová, T. The use of constructed wetlands for removal of pesticides from agricultural runoff and drainage: A review. Environ. Int. 2015, 75, 11-20. [CrossRef] [PubMed]

19. Passeport, E.; Benoit, P.; Bergheaud, V.; Coquet, Y.; Tournebize, J. Selected pesticides adsorption and desorption in substrates from artificial wetland and forest buffer. Environ. Toxicol. Chem. 2011, 30, 1669-1676. [CrossRef] [PubMed]

20. Passeport, E.; Benoit, P.; Bergheaud, V.; Coquet, Y.; Tournebize, J. Epoxiconazole degradation from artificial wetland and forest buffer substrates under flooded conditions. Chem. Eng. J. 2011, 173, 760-765. [CrossRef]

21. Imfeld, G.; Lefrancq, M.; Maillard, E.; Payraudeau, S. Transport and attenuation of dissolved glyphosate and AMPA in a stormwater wetland. Chemosphere 2013, 90, 1333-1339. [CrossRef]

22. Krone-Davis, P.; Watson, F.; Huertos, M.L.; Starner, K. Assessing pesticide reduction in constructed wetlands using a tanks-inseries model within a Bayesian framework. Ecol. Eng. 2013, 57, 342-352. [CrossRef]

23. Oeurng, C.; Sauvage, S.; Sánchez-Pérez, J.-M. Assessment of hydrology, sediment and particulate organic carbon yield in a large agricultural catchment using the SWAT model. J. Hydrol. 2011, 401, 145-153. [CrossRef]

24. Zhang, X.; Zhang, M. Modeling effectiveness of agricultural BMPs to reduce sediment load and organophosphate pesticides in surface runoff. Sci. Total. Environ. 2011, 409, 1949-1958. [CrossRef] 
25. Marican, A.; Durán-Lara, E.F. A review on pesticide removal through different processes. Environ. Sci. Pollut. Res. 2018, 25, 2051-2064. [CrossRef] [PubMed]

26. Chen, C.; Jia, Z.; Luo, W.; Hong, J.; Yin, X.; Chen, C. Efficiency of different monitoring units in representing pollutant removals in distributed ditches and ponds in agricultural landscapes. Ecol. Indic. 2020, 108, 105677. [CrossRef]

27. Krause, S.; Lewandowski, J.; Grimm, N.B.; Hannah, D.M.; Pinay, G.; McDonald, K.; Martí, E.; Argerich, A.; Pfister, L.; Klaus, J.; et al. Ecohydrological interfaces as hot spots of ecosystem processes. Water Resour. Res. 2017, 53, 6359-6376. [CrossRef]

28. Elsner, M.; Imfeld, G. Compound-specific isotope analysis (CSIA) of micropollutants in the environment-Current developments and future challenges. Curr. Opin. Biotechnol. 2016, 41, 60-72. [CrossRef] [PubMed]

29. Garlapati, D.; Charankumar, B.; Ramu, K.; Madeswaran, P.; Murthy, M.V.R. A review on the applications and recent advances in environmental DNA (eDNA) metagenomics. Rev. Environ. Sci. Bio Technol. 2019, 18, 389-411. [CrossRef]

30. Han, B.; Zhang, S.; Wang, P.; Wang, C. Effects of water flow on submerged macrophyte-biofilm systems in constructed wetlands. Sci. Rep. 2018, 8, 1-12. [CrossRef] [PubMed]

31. Li, Y.; Feng, W.; Chi, H.; Huang, Y.; Ruan, D.; Chao, Y.; Qiu, R.; Wang, S. Could the rhizoplane biofilm of wetland plants lead to rhizospheric heavy metal precipitation and iron-sulfur cycle termination? J. Soils Sediments 2019, 19, 3760-3772. [CrossRef]

32. Sura, S.; Waiser, M.; Tumber, V.; Farenhorst, A. Effects of herbicide mixture on microbial communities in prairie wetland ecosystems: A whole wetland approach. Sci. Total. Environ. 2012, 435-436, 34-43. [CrossRef]

33. Hedgespeth, M.L.; Nichols, E.G. Expanding phytoremediation to the realms of known and unknown organic chemicals of concern. Int. J. Phytoremediation 2019, 21, 1385-1396. [CrossRef] [PubMed]

34. Elsayed, O.; Maillard, E.; Vuilleumier, S.; Nijenhuis, I.; Richnow, H.; Imfeld, G. Using compound-specific isotope analysis to assess the degradation of chloroacetanilide herbicides in lab-scale wetlands. Chemosphere 2014, 99, 89-95. [CrossRef]

35. Imfeld, G.; Aragonés, C.E.; Zeiger, S.; von Eckstädt, C.V.; Paschke, H.; Trabitzsch, R.; Weiss, H.; Richnow, H.H. Tracking in situ Biodegradation of 1,2-Dichloroethenes in a Model Wetland. Environ. Sci. Technol. 2008, 42, 7924-7930. [CrossRef] [PubMed]

36. Meckenstock, R.U.; Morasch, B.; Griebler, C.; Richnow, H.H. Stable isotope fractionation analysis as a tool to monitor biodegradation in contaminated acquifers. J. Contam. Hydrol. 2004, 75, 215-255. [CrossRef] [PubMed]

37. Rakoczy, J.; Remy, B.; Vogt, C.; Richnow, H.H. A Bench-Scale Constructed Wetland As a Model to Characterize Benzene Biodegradation Processes in Freshwater Wetlands. Environ. Sci. Technol. 2011, 45, 10036-10044. [CrossRef] [PubMed]

38. Lollar, B.S.; Slater, G.; Ahad, J.; Sleep, B.; Spivack, J.; Brennan, M.; MacKenzie, P. Contrasting carbon isotope fractionation during biodegradation of trichloroethylene and toluene: Implications for intrinsic bioremediation. Org. Geochem. 1999, 30, 813-820. [CrossRef]

39. Elsner, M. Stable isotope fractionation to investigate natural transformation mechanisms of organic contaminants: Principles, prospects and limitations. J. Environ. Monit. 2010, 12, 2005-2031. [CrossRef] [PubMed]

40. Torabi, E.; Wiegert, C.; Guyot, B.; Vuilleumier, S.; Imfeld, G. Dissipation of S-metolachlor and butachlor in agricultural soils and responses of bacterial communities: Insights from compound-specific isotope and biomolecular analyses. J. Environ. Sci. 2020, 92, 163-175. [CrossRef]

41. Melsbach, A.; Torrentó, C.; Ponsin, V.; Bolotin, J.; Lachat, L.; Prasuhn, V.; Hofstetter, T.B.; Hunkeler, D.; Elsner, M. Dual-Element Isotope Analysis of Desphenylchloridazon to Investigate Its Environmental Fate in a Systematic Field Study: A Long-Term Lysimeter Experiment. Environ. Sci. Technol. 2020, 54, 3929-3939. [CrossRef] [PubMed]

42. Pérez-Rodríguez, P.; Schmitt, A.-D.; Gangloff, S.; Masbou, J.; Imfeld, G. Plants affect the dissipation and leaching of anilide pesticides in soil mesocosms: Insights from compound-specific isotope analysis (CSIA). Agric. Ecosyst. Environ. 2021, $308,107257$. [CrossRef]

43. Alvarez-Zaldívar, P.; Payraudeau, S.; Meite, F.; Masbou, J.; Imfeld, G. Pesticide degradation and export losses at the catchment scale: Insights from compound-specific isotope analysis (CSIA). Water Res. 2018, 139, 198-207. [CrossRef]

44. Lange, J.; Schuetz, T.; Grégoire, C.; Elsasser, D.; Schulz, R.; Passeport, E.; Tournebize, J. Multi-tracer experiments to characterise contaminant mitigation capacities for different types of artificial wetlands. Int. J. Environ. Anal. Chem. 2011, 91, 768-785. [CrossRef]

45. Fernández-Pascual, E.; Bork, M.; Hensen, B.; Lange, J. Hydrological tracers for assessing transport and dissipation processes of pesticides in a model constructed wetland system. Hydrol. Earth Syst. Sci. 2020, 24, 41-60. [CrossRef]

46. Ye, J.; Zhao, M.; Niu, L.; Liu, W. Enantioselective Environmental Toxicology of Chiral Pesticides. Chem. Res. Toxicol. 2015, 28, 325-338. [CrossRef] [PubMed]

47. Lefrancq, M.; Jadas-Hécart, A.; La Jeunesse, I.; Landry, D.; Payraudeau, S. High frequency monitoring of pesticides in runoff water to improve understanding of their transport and environmental impacts. Sci. Total. Environ. 2017, 587-588, 75-86. [CrossRef] [PubMed]

48. Maillard, E.; Lange, J.; Schreiber, S.; Dollinger, J.; Herbstritt, B.; Millet, M.; Imfeld, G. Dissipation of hydrological tracers and the herbicide S-metolachlor in batch and continuous-flow wetlands. Chemosphere 2016, 144, 2489-2496. [CrossRef] [PubMed]

49. Masbou, J.; Meite, F.; Guyot, B.; Imfeld, G. Enantiomer-specific stable carbon isotope analysis (ESIA) to evaluate degradation of the chiral fungicide Metalaxyl in soils. J. Hazard. Mater. 2018, 353, 99-107. [CrossRef]

50. Gutknecht, J.L.M.; Goodman, R.M.; Balser, T.C. Linking soil process and microbial ecology in freshwater wetland ecosystems. Plant. Soil 2006, 289, 17-34. [CrossRef] 
51. Imfeld, G.; Vuilleumier, S. Measuring the effects of pesticides on bacterial communities in soil: A critical review. Eur. J. Soil Biol. 2012, 49, 22-30. [CrossRef]

52. Lyu, T.; Zhang, L.; Xu, X.; Arias, C.A.; Brix, H.; Carvalho, P.N. Removal of the pesticide tebuconazole in constructed wetlands: Design comparison, influencing factors and modelling. Environ. Pollut. 2018, 233, 71-80. [CrossRef]

53. Feld, L.; Hjelmsø, M.H.; Nielsen, M.S.; Jacobsen, A.D.; Rønn, R.; Ekelund, F.; Krogh, P.H.; Strobel, B.W.; Jacobsen, C.S. Pesticide Side Effects in an Agricultural Soil Ecosystem as Measured by amoA Expression Quantification and Bacterial Diversity Changes. PLoS ONE 2015, 10, e0126080. [CrossRef]

54. Chará-Serna, A.M.; Epele, L.B.; Morrissey, C.A.; Richardson, J.S. Nutrients and sediment modify the impacts of a neonicotinoid insecticide on freshwater community structure and ecosystem functioning. Sci. Total. Environ. 2019, 692, 1291-1303. [CrossRef] [PubMed]

55. Su, X.; Chen, Y.; Wang, Y.; Yang, X.; He, Q. Disturbances of electron production, transport and utilization caused by chlorothalonil are responsible for the deterioration of soil denitrification. Soil Biol. Biochem. 2019, 134, 100-107. [CrossRef]

56. Su, X.; Chen, Y.; Wang, Y.; Yang, X.; He, Q. Impacts of chlorothalonil on denitrification and N2O emission in riparian sediments: Microbial metabolism mechanism. Water Res. 2019, 148, 188-197. [CrossRef]

57. Mauffrey, F.; Baccara, P.-Y.; Gruffaz, C.; Vuilleumier, S.; Imfeld, G. Bacterial Community Composition and Genes for Herbicide Degradation in a Stormwater Wetland Collecting Herbicide Runoff. Water Air Soil Pollut. 2017, 228, 452. [CrossRef]

58. Gaullier, C.; Dousset, S.; Billet, D.; Baran, N. Is pesticide sorption by constructed wetland sediments governed by water level and water dynamics? Environ. Sci. Pollut. Res. 2018, 25, 14324-14335. [CrossRef] [PubMed]

59. Do macrophytes play a role in constructed treatment wetlands? Water Sci. Technol. 1997, 35, 11-17. [CrossRef]

60. Sánchez-Pérez, J.; Montuelle, B.; Mouchet, F.; Gauthier, L.; Julien, F.; Sauvage, S.; Teissier, S.; Dedieu, K.; Destrieux, D.; Vervier, P.; et al. Role of the hyporheic heterotrophic biofilm on transformation and toxicity of pesticides. Ann. Limnol. Int. J. Limnol. 2013, 49, 87-95. [CrossRef]

61. Babcsányi, I.; Meite, F.; Imfeld, G. Biogeochemical gradients and microbial communities in Winogradsky columns established with polluted wetland sediments. FEMS Microbiol. Ecol. 2017, 93, 93. [CrossRef]

62. Carluer, N.; Noll, D.; Bernard, K.; Fontaine, A.; Lauvernet, C. Dimensionner les zones tampons enherbées et boisées pour réduire le transfert hydrique des produits phytosanitaires. Tech. Sci. Méthodes 2014, 101-120. [CrossRef]

63. Babcsányi, I.; Imfeld, G.; Granet, M.; Chabaux, F. Copper Stable Isotopes to Trace Copper Behavior in Wetland Systems. Environ. Sci. Technol. 2014, 48, 5520-5529. [CrossRef]

64. Budd, R.; O'Geen, A.; Goh, K.S.; Bondarenko, S.; Gan, J. Removal mechanisms and fate of insecticides in constructed wetlands Chemosphere 2011, 83, 1581-1587. [CrossRef]

65. Honti, M.; Fenner, K. Deriving Persistence Indicators from Regulatory Water-Sediment Studies-Opportunities and Limitations in OECD 308 Data. Environ. Sci. Technol. 2015, 49, 5879-5886. [CrossRef]

66. Kaufman, M.H.; Cardenas, M.B.; Buttles, J.; Kessler, A.J.; Cook, P.L.M. Hyporheic hot moments: Dissolved oxygen dynamics in the hyporheic zone in response to surface flow perturbations. Water Resour. Res. 2017, 53, 6642-6662. [CrossRef]

67. Guan, M.; Ahilan, S.; Yu, D.; Peng, Y.; Wright, N. Numerical modelling of hydro-morphological processes dominated by fine suspended sediment in a stormwater pond. J. Hydrol. 2018, 556, 87-99. [CrossRef]

68. Silva, G.; Ginzburg, I. Stokes-Brinkman-Darcy Solutions of Bimodal Porous Flow Across Periodic Array of Permeable Cylindrical Inclusions: Cell Model, Lubrication Theory and LBM/FEM Numerical Simulations. Transp. Porous Media 2016, 111, 795-825. [CrossRef]

69. Chen, W.; Nover, D.; Yen, H.; Xia, Y.; He, B.; Sun, W.; Viers, J. Exploring the multiscale hydrologic regulation of multipond systems in a humid agricultural catchment. Water Res. 2020, 184, 115987. [CrossRef]

70. Amin, M.G.M.; Veith, T.L.; Shortle, J.S.; Karsten, H.D.; Kleinman, P.J.A. Addressing the spatial disconnect between national-scale total maximum daily loads and localized land management decisions. J. Environ. Qual. 2020, 49, 613-627. [CrossRef] [PubMed]

71. Engebretsen, A.; Vogt, R.D.; Bechmann, M. SWAT model uncertainties and cumulative probability for decreased phosphorus loading by agricultural Best Management Practices. Catena 2019, 175, 154-166. [CrossRef]

72. Watanabe, H.; Takagi, K. A Simulation Model for Predicting Pesticide Concentrations in Paddy Water and Surface Soil II. Model Validation and Application. Environ. Technol. 2000, 21, 1393-1404. [CrossRef]

73. Fu, B.; Merritt, W.S.; Croke, B.F.; Weber, T.R.; Jakeman, A.J. A review of catchment-scale water quality and erosion models and a synthesis of future prospects. Environ. Model. Softw. 2019, 114, 75-97. [CrossRef]

74. Battiato, I.; Rubol, S. Single-parameter model of vegetated aquatic flows. Water Resour. Res. 2014, 50, 6358-6369. [CrossRef]

75. Arnold, J.G.; Srinivasan, R.; Muttiah, R.S.; Williams, J.R. Large Area Hydrologic Modeling and Assessment Part I: Model Development. JAWRA J. Am. Water Resour. Assoc. 1998, 34, 73-89. [CrossRef]

76. Almeida-Dias, J.; Figueira, J.; Roy, B. A multiple criteria sorting method where each category is characterized by several reference actions: The Electre Tri-nC method. Eur. J. Oper. Res. 2012, 217, 567-579. [CrossRef]

77. Macary, F.; Almeida-Dias, J.; Uny, D.; Probst, A. Assessment of the effects of best environmental practices on reducing pesticide contamination in surface water, using multi-criteria modelling combined with a GIS. Int. J. Multicriteria Decis. Mak. $2013,3,178$. [CrossRef]

78. Macary, F.; Morin, S.; Probst, J.-L.; Saudubray, F. A multi-scale method to assess pesticide contamination risks in agricultural watersheds. Ecol. Indic. 2014, 36, 624-639. [CrossRef] 
79. Billen, G.; Garnier, J.; Silvestre, M. A simplified algorithm for calculating benthic nutrient fluxes in river systems. Ann. Limnol. Int. J. Limnol. 2015, 51, 37-47. [CrossRef]

80. Gaillardet, J.; Braud, I.; Hankard, F.; Anquetin, S.; Bour, O.; Dorfliger, N.; De Dreuzy, J.; Galle, S.; Galy, C.; Gogo, S.; et al. OZCAR: The French Network of Critical Zone Observatories. Vadose Zone J. 2018, 17, 180067. [CrossRef]

81. Mougin, C.; Gouy, V.; Bretagnolle, V.; Berthou, J.; Andrieux, P.; Ansart, P.; Benoit, M.; Coeurdassier, M.; Comte, I.; Dagès, C.; et al. RECOTOX, a French initiative in ecotoxicology-toxicology to monitor, understand and mitigate the ecotoxicological impacts of pollutants in socioagroecosystems. Environ. Sci. Pollut. Res. 2018, 25, 33882-33894. [CrossRef]

82. Bretagnolle, V.; Benoit, M.; Bonnefond, M.; Breton, V.; Church, J.M.; Gaba, S.; Gilbert, D.; Gillet, F.; Glatron, S.; Guerbois, C.; et al. Action-orientated research and framework: Insights from the French long-term social-ecological research network. Ecol. Soc. 2019, 24. [CrossRef]

83. Boithias, L.; Sauvage, S.; Taghavi, L.; Merlina, G.; Probst, J.-L.; Pérez, J.M.S. Occurrence of metolachlor and trifluralin losses in the Save river agricultural catchment during floods. J. Hazard. Mater. 2011, 196, 210-219. [CrossRef]

84. Taghavi, L.; Merlina, G.; Probst, J.-L. The role of storm flows in concentration of pesticides associated with particulate and dissolved fractions as a threat to aquatic ecosystems-Case study: The agricultural watershed of Save river (Southwest of France). Knowl. Manag. Aquat. Ecosyst. 2011, 6, 06. [CrossRef]

85. Headley, T.R.; Kadlec, R.H. Conducting hydraulic tracer studies of constructed wetlands: A practical guide. Ecohydrol. Hydrobiol. 2007, 7, 269-282. [CrossRef]

86. Tsavdaris, A.; Williams, J.B.; Mitchell, S. An experimental evaluation of sustainable drainage systems. J. Urban. Environ. Eng. 2013, 7, 206-214. [CrossRef]

87. German, J.; Jansons, K.; Svensson, G.; Karlsson, D.; Gustafsson, L.-G. Modelling of different measures for improving removal in a stormwater pond. Water Sci. Technol. 2005, 52, 105-112. [CrossRef]

88. Kang, H. Flow characteristics and morphological changes in open-channel flows with alternate vegetation zones. KSCE J. Civ. Eng. 2013, 17, 1157-1165. [CrossRef]

89. Drouin, G.; Fahs, M.; Droz, B.; Younes, A.; Imfeld, G.; Payraudeau, S. Pollutant Dissipation at the Sediment-Water Interface: A Robust Discrete Continuum Numerical Model and Recirculating Laboratory Experiments. Water Resour. Res. 2021, 57. [CrossRef]

90. García, J.; Solimeno, A.; Zhang, L.; Marois, D.; Mitsch, W.J. Constructed wetlands to solve agricultural drainage pollution in South Florida: Development of an advanced simulation tool for design optimization. J. Clean. Prod. 2020, 258, 120868. [CrossRef]

91. Berg, P.; Rysgaard, S.; Thamdrup, B. Dynamic Modeling of Early Diagenesis and Nutrient Cycling. A Case Study in an Artic Marine Sediment. Am. J. Sci. 2003, 303, 905-955. [CrossRef]

92. Van Breukelen, B.M. Quantifying the Degradation and Dilution Contribution to Natural Attenuation of Contaminants by Means of an Open System Rayleigh Equation. Environ. Sci. Technol. 2007, 41, 4980-4985. [CrossRef] [PubMed]

93. Lutz, S.R.; Van Der Velde, Y.; Elsayed, O.F.; Imfeld, G.; Lefrancq, M.; Payraudeau, S.; Van Breukelen, B.M. Pesticide fate on catchment scale: Conceptual modelling of stream CSIA data. Hydrol. Earth Syst. Sci. 2017, 21, 5243-5261. [CrossRef]

94. Alvarez-Zaldívar, P.; Centler, F.; Maier, U.; Thullner, M.; Imfeld, G. Biogeochemical modelling of in situ biodegradation and stable isotope fractionation of intermediate chloroethenes in a horizontal subsurface flow wetland. Ecol. Eng. 2016, 90, 170-179. [CrossRef]

95. Beven, K.; Binley, A. GLUE: 20 years on. Hydrol. Process. 2014, 28, 5897-5918. [CrossRef]

96. Shao, Q.; Fahs, M.; Younes, A.; Makradi, A. A high-accurate solution for Darcy-Brinkman double-diffusive convection in saturated porous media. Numer. Heat Transfer Part. B Fundam. 2016, 69, 26-47. [CrossRef]

97. Abimbola, O.; Mittelstet, A.; Messer, T.; Berry, E.; van Griensven, A. Modeling and Prioritizing Interventions Using Pollution Hotspots for Reducing Nutrients, Atrazine and E. coli Concentrations in a Watershed. Sustainability 2020, 13, 103. [CrossRef]

98. Liu, Y.; Guo, T.; Wang, R.; Engel, B.A.; Flanagan, D.C.; Li, S.; Pijanowski, B.C.; Collingsworth, P.D.; Lee, J.G.; Wallace, C.W. A SWAT-based optimization tool for obtaining cost-effective strategies for agricultural conservation practice implementation at watershed scales. Sci. Total. Environ. 2019, 691, 685-696. [CrossRef] [PubMed]

99. Arnold, J.G.; Allen, P.M.; Bernhardt, G. A comprehensive surface-groundwater flow model. J. Hydrol. 1993, 142, 47-69. [CrossRef]

100. Wang, R.; Yuan, Y.; Yen, H.; Grieneisen, M.; Arnold, J.; Wang, D.; Wang, C.; Zhang, M. A review of pesticide fate and transport simulation at watershed level using SWAT: Current status and research concerns. Sci. Total. Environ. 2019, 669, 512-526. [CrossRef]

101. Quilbé, R.; Rousseau, A.N.; Lafrance, P.; Leclerc, J.; Amrani, M. Selecting a Pesticide Fate Model at the Watershed Scale Using a Multi-criteria Analysis. Water Qual. Res. J. 2006, 41, 283-295. [CrossRef]

102. Tan, M.L.; Gassman, P.W.; Yang, X.; Haywood, J. A review of SWAT applications, performance and future needs for simulation of hydro-climatic extremes. Adv. Water Resour. 2020, 143, 103662. [CrossRef]

103. Macary, F.; Dias, J.A.; Figueira, J.R.; Roy, B. A Multiple Criteria Decision Analysis Model Based on ELECTRE TRI-C for Erosion Risk Assessment in Agricultural Areas. Environ. Model. Assess. 2014, 19, 221-242. [CrossRef]

104. Ferrant, S.; Oehler, F.; Durand, P.; Ruiz, L.; Salmon-Monviola, J.; Justes, E.; Dugast, P.; Probst, A.; Probst, J.-L.; Sánchez-Pérez, J.-M. Understanding nitrogen transfer dynamics in a small agricultural catchment: Comparison of a distributed (TNT2) and a semi distributed (SWAT) modeling approaches. J. Hydrol. 2011, 406, 1-15. [CrossRef]

105. Macary, F.; Leccia, O.; Dias, J.A.; Morin, S.; Sánchez-Pérez, J.-M. Agro-environmental risk evaluation by a spatialised multi-criteria modelling combined with the PIXAL method. Rev. Int. Géomatique 2013, 23, 39-70. [CrossRef] 
106. Macary, F.; Ombredane, D.; Uny, D. A multicriteria spatial analysis of erosion risk into small watersheds in the low Normandy bocage (France) by ELECTRE III method coupled with a GIS. Int. J. Multicriteria Decis. Mak. 2010, 1, 25. [CrossRef]

107. Gassmann, M.; Olsson, O.; Stamm, C.; Weiler, M.; Kümmerer, K. Physico-chemical characteristics affect the spatial distribution of pesticide and transformation product loss to an agricultural brook. Sci. Total. Environ. 2015, 532, 733-743. [CrossRef] [PubMed]

108. Droz, B.; Drouin, G.; Maurer, L.; Villette, C.; Payraudeau, S.; Imfeld, G. Phase Transfer and Biodegradation of Pesticides in Water-Sediment Systems Explored by Compound-Specific Isotope Analysis and Conceptual Modeling. Environ. Sci. Technol. 2021, 55, 4720-4728. [CrossRef]

109. Neitsch, S.L.; Arnold, J.G.; Kiniry, J.R.; Williams, J.R. Soil and Water Assessment Tool Theoretical Documentation Version 2009 Texas Water Resources Institute Technical Report, No. 406; Texas Water Resources Institute: College Station, TX, USA, 2011.

110. Gobas, F.A.; Lai, H.-F.; Mackay, D.; Padilla, L.E.; Goetz, A.; Jackson, S.H. AGRO-2014: A time dependent model for assessing the fate and food-web bioaccumulation of organic pesticides in farm ponds: Model testing and performance analysis. Sci. Total. Environ. 2018, 639, 1324-1333. [CrossRef]

111. Luo, Y.; Zhang, M. Management-oriented sensitivity analysis for pesticide transport in watershed-scale water quality modeling using SWAT. Environ. Pollut. 2009, 157, 3370-3378. [CrossRef] 